\title{
Immunoglobulin G4-related hypertrophic pachymeningitis
}

\section{A case-oriented review}

Michaël Levraut, MD, Mikaël Cohen, MD, Saskia Bresch, MD, Caroline Giordana, MD, Fanny Burel-Vandenbos, MD, PhD, Lydiane Mondot, MD, Jacques Sedat, MD, Denys Fontaine, MD, PhD, Véronique Bourg, MD, Nihal Martis, MD, and Christine Lebrun-Frenay, MD, PhD

Neurol Neuroimmunol Neuroinflamm 2019;6:e568. doi:10.1212/NXI.0000000000000568

\section{Abstract}

\section{Objective}

Meningeal involvement in Immunoglobulin G (IgG)-4-related disease is rare and only described in case reports and series. Because a review into the disease is lacking, we present 2 cases followed by a literature review of IgG4-related hypertrophic pachymeningitis (IgG4-HP).

\section{Methods}

Two IgG4-HP cases were reported, one involving the spinal cord and responding to surgical management and a second involving the brain and responding to Rituximab therapy. We then review clinical cases and case-series of histologically proven IgG4-HP that were published in the PubMed-NCBI database.

\section{Results}

Forty-two case reports and 5 case-series were studied (60 patients, 20 women). The median age was 53. Eighteen patients had systemic involvement and 24 had single-organ IgG4-HP. Fiftyfive percent of patients had an elevated serum IgG4. Treatment was surgical in 20/53 cases. Steroid therapy and immunosuppressors were effective in $85 \%$ and more than $90 \%$ of the cases, respectively. The rate of disease relapse was $42.1 \%$ after steroid therapy was discontinued.

\section{Discussion/conclusion}

IgG4-HP is characterized by the lack of extra-neurologic organ-involvement and systemic signs. Histopathologic studies should be performed as it is crucial for diagnosis because serum markers are rarely informative. 18F-FDG positon tomography can be useful to characterize systemic forms. There is no specific CSF marker for IgG4-HP and the diagnostic value of CSF IgG4 levels needs to be studied with larger samples. We provide a treatment algorithm for IgG4HP. Such treatment strategies rely on early surgery, steroids, and early immunosuppressive therapy to prevent neurologic complications.

\author{
Correspondence \\ Dr. Levraut \\ michael.levraut@gmail.com
}




\section{Glossary}

CYC = cyclophosphamide; GPA = granulomatosis with polyangeitis; HPF = high-power field; IgG4 = immunoglobulin G4; IgG4-HP = IgG 4-related hypertrophic pachymeningitis; IgG4-RD = IgG 4-related disease; RI = Responder Index; RTX = Rituximab; WBC = white blood cell.

Immunoglobulin G (IgG)-4-related disease (IgG4-RD) is a polyclonal lymphoproliferative disorder affecting many organs. Diagnosis is histologic and shows lymphoplasmocytic infiltration with IgG4+ plasma cell proliferation, storiform fibrosis, and obliterative phlebitis. ${ }^{1,2}$ The pancreas, salivary glands, retroperitoneum, and lymph nodes are the most commonly affected. ${ }^{3-7}$ Central neurologic manifestations are rare with reports of mostly hypertrophic pachymeningitis (HP) and hypophysitis. Previous studies have found that retrospective analyses of idiopathic $\mathrm{HP}$ were able to ultimately identify IgG4-RD in several cases. ${ }^{4}$ Specific diagnostic criteria have been defined for HP associated with IgG4-RD (IgG4$\mathrm{HP})$, which rely on histopathologic analysis. ${ }^{7}$ Unfortunately, because of its scarcity, only case reports and a few case series of IgG4-HP are available in the medical literature. No treatment algorithm is known for this uncommon location of IgG4-RD where relapsing occurs frequently. Because a better understanding of the disease is needed, we report 2 cases and a literature review of the clinical, biological, and treatment specificities of IgG4-HP.

\section{Case reports}

\section{Case 1}

A 55-year-old Caucasian male with a history of genetic hemochromatosis, diabetes mellitus, and high blood pressure presented with a progressive walking difficulty over a 2-week period. Clinical examination reported T2-T3 dorsalgia, severe paresis with pyramidal syndrome, decreased vibratory sensation of the lower limbs, and bladder dysfunction. There was no weight loss, asthenia, fever, or extra-neurologic abnormalities. Spinal cord MRI revealed many cervico-thoracic T2/ fluid attenuated inversion recovery hyper intense signals from C3 to T3 that were all enhanced by gadolinium injection revealing active inflammatory myelitis. Spinal venous dilatation of the cervico-thoracic junction suggestive of dural fistula was also reported (figure 1, A). The brain MRI was normal as were visual evoked potentials. Blood tests did not reveal an inflammatory syndrome (the C-Reactive protein level was below $5 \mathrm{mg} / \mathrm{L}$ and fibrinogenemia was $3.15 \mathrm{~g} / \mathrm{L}$ ). Immunologic and infectious assessment did not help the diagnosis. Anti-aquaporin 4 and myelin oligodendrocyte glycoprotein auto-antibodies were negative. Analysis of the CSF revealed elevated protein levels $(1.96 \mathrm{~g} / \mathrm{L})$ and lymphocytic meningitis (69 white blood cells [WBCs] $/ \mathrm{mm} 3$ with $95 \%$ of lymphocytes). Viral PCR testing and CSF cytology were not informative. The CSF IgG index was 0.53 despite a high level of CSF IgG $(18.7 \mathrm{mg} / \mathrm{dL})$ and there was no oligoclonal band. CSF levels of Interleukin-6 were high at $1923 \mathrm{pg} / \mathrm{mL}$.
Treatment with IV corticosteroids ( $1 \mathrm{~g}$ per day for 5 days) resulted in partial regression of neurologic signs. Spinal cord arteriography confirmed the diagnosis of a dural fistula that was treated by embolization (figure 1, A). Three months later, the MRI showed complete regression of spinal cord lesions. The patient was able to walk without limitation to the walking perimeter. Only mild proximal motor weakness and proprioceptive ataxia of the lower limbs persisted.

The same patient presented to our department 3 years later with similar neurologic features. The MRI of the spine found a posterior $\mathrm{T} 1$ isointense signal intensively enhanced with gadolinium and a $\mathrm{T} 2$ hypointense signal related to an intradural, extra-medullary, posterior, and compressive tumor-like lesion regarding T2-T3 surrounded with edema (figure 1, B). Surgical subtotal resection of the lesion was performed and confirmed its extramedullary location, originating from the dura and highly adherent to the spinal cord pia mater. Histopathologic examination of the surgical specimen identified a fibro-inflammatory lesion with dural thickening due to a lymphoplasmocytic infiltrate, storiform fibrosis, and obliterative vasculitis. Immunohistochemical analysis showed a polyclonal lymphocytic infiltration (expression of both kappa and lambda light chains) including 53 IgG4+ plasma cells per high-power field (HPF) and an $\mathrm{IgG} 4+/ \mathrm{IgG}$ ratio greater than $40 \%$ (figure e-1a, links.lww.com/NXI/A115). There was no evidence of malignant, meningiomatous, or histiocytic disease (negativity of epithelial markers cytokeratin and Epithelial Membrane Antigen, progesterone receptors, protein S100, CD1a, langherin, and Anaplastic Lymphoma Kinase). Staining for microbial pathogens (Gram, GomoriGrocott and Ziehl) was negative. Plasma IgG4 levels were, however, normal $(59 \mathrm{mg} / \mathrm{dL})$. There was neither eosinophilia nor complement consumption. [18F]-fluorodeoxyglucose positron emission tomography (FDG PET) (PET-CT) did not document other lesions. IgG4-HP was diagnosed based on histopathologic criteria.

Near-complete clinical recovery was achieved 3 months after surgery. Bladder dysfunction had subsided and walking did not require help. Nevertheless, proprioceptive disorders of the lower limbs persisted. The MRI did not find residual lesions. Given the patient's history of diabetes mellitus, steroids were not initiated, and a close follow-up attitude was adopted.

\section{Case 2}

A 66-year-old Caucasian male with a history of high blood pressure, dyslipidemia, and smoking presented to the emergency department for subacute onset of non-painful bilateral loss of vision. He had been suffering from chronic pulsatile 

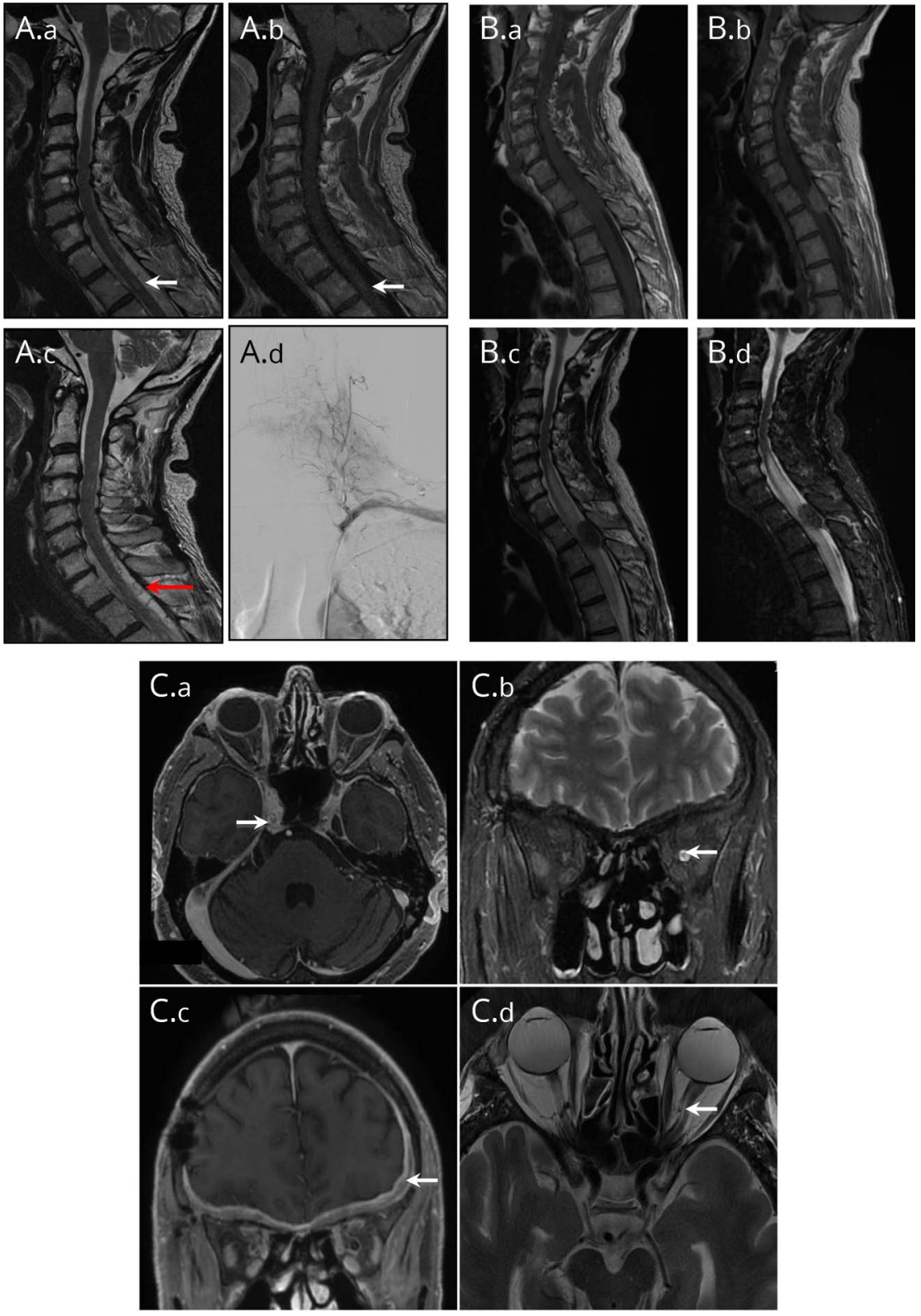

(A) Multiple T2 hyperintense signals (white arrows) (A.a) all enhanced after gadolinium injection (A.b) of the posterior half of the cervico-thoracic spinal cord. T2 hypointense signal of the posterior subarachnoid space from C5 to D3 suggesting a dural fistula (red arrow) (A.C), confirmed by medullary arteriography (A.d) with opacification of a venous peloton opposite the meninge of the left lateral part of the dural sheath corresponding to the medullary veins visible on MRI. (B) Intra-ductal, intra-dural, postero-median, polylobulated tumor lesion, well-defined, in T1 isointense signal (B.a), intensely and homogeneously enhanced after injection of gadolinium (B.b), T2 hypointense signal (B.C), next to D2-D3 realizing a mass effect on the spinal cord. There is an extensive intramedullary edema supra and under-lesion (B.d). (C) Bi-frontal meningeal thickening enhanced by gadolinium invading the sheaths of optic nerves and cavernous sinuses (white arrows) (C.a and c). T2/FLAIR hyperintense signal of the left optic nerve testifying to radiologic optic neuritis, white arrows (C.b d). FLAIR = fluid attenuated inversion recovery. headaches for many months. There was no fever or weight loss. Physical examination revealed ptosis and left reactive mydriasis with a decrease in bilateral visual acuity at 5/10 in the right eye and less than $1 / 20$ (light perception) in the left eye. Neurologic and general somatic examinations were normal. Visual evoked potentials revealed a bilateral severe axomyelenic defect in both eyes. Funduscopic examination showed left temporal pale retina. A brain MRI found a gadolinium-enhanced, bi-frontal meningeal thickening invading the optic nerve sheaths and cavernous sinuses (figure 1, C). Microbial analyses and the immunologic bioassay were not informative. There was no inflammatory syndrome, eosinophilia, or complement consumption. Hypogammaglobulinemia was found on electrophoresis of plasma proteins. Plasma IgG4 levels were normal $(40.1 \mathrm{mg} / \mathrm{dL})$.
The CSF opening pressure was normal and its analysis showed protein levels of $0.99 \mathrm{~g} / \mathrm{L}$ without pleocytosis $\left(2 \mathrm{WBC} / \mathrm{mm}^{3}\right)$ or inflammatory markers (IgG index of 0.63 and CSF IgG-levels at $6.29 \mathrm{mg} / \mathrm{dL})$. Interleukins-6 and -10 levels were also normal. Meningeal biopsy identified an inflammatory infiltrate rich in IgG4+ plasma cells with perivascular storiform fibrosis and obliterative phlebitis. Immunostaining showed more than 10 IgG4-positive plasma cells per HPF. The IgG4+/IgG ratio was greater than $40 \%$ (figure e-1b, links.lww.com/NXI/A115). PET-CT did not show pathologic hypermetabolism. The diagnosis of IgG4-HP was made.

Corticosteroid therapy $(1 \mathrm{mg} / \mathrm{kg} / \mathrm{d})$ after pulse IV methylprednisolone for 5 days at $1 \mathrm{~g}$ q.d. was introduced, but it was 
ineffective. IV Rituximab (RTX) was started 12 months later ( $1 \mathrm{~g}$ day 1 and day 15) and was followed by maintenance treatment (M8). Fifteen months later, clinical and radiologic improvement was observed with partial regression of headaches and recovery of visual acuity at 10/10 in the right eye and less than 1/20 (movements of the hand perceived at 50 $\mathrm{cm}$ ) in the left eye. At follow-up 1 year later, a brain MRI showed the complete regression of meningeal thickening.

\section{A systematic review}

\section{Methods and definitions}

We reviewed clinical cases and case-series of cerebral and spinal cord HP with histologically proven IgG4-RD that were published between January 2008 and September 2017 in the PubMedNCBI database. The key words used in the search were "Pachymeningitis," "IgG4-related disease," "HP," "IgG4-HP," "IgG4 neurologic impairment," and "IgG4 CNS." Demographics, clinical and biological data, pathology features, and treatment strategies were collected for each patient, when available.

Diagnostic criteria are those of the Japan College of Rheumatology ${ }^{8}$ :

1. A clinical study showed characteristic diffuse/localized swelling or masses in single or multiple organs

2. A hematologic study showed elevated levels of serum IgG4 (135 mg/dL or higher)

3. A histopathologic study showed the following 2 findings:

- Histologic findings: marked lymphocyte and plasmocytic infiltration and fibrosis

- IgG4-positive plasma cell infiltration: ratio of IgG4/ IgG positive cell $>40 \%$ and IgG4-positive plasma cells/ $\mathrm{HPF}>10$

When $(1)+(2)+(3)$ are fulfilled, it is definite.

When $(1)+(3)$ are fulfilled, it is probable.

When $(1)+(2)$ are fulfilled, it is possible.

Isolated IgG4-HP was characterized by the absence of extrameningeal organ-involvement (including the pituitary gland). Mutually exclusive lesions of the brain or spinal cord defined "single-organ pachymeningitis." When extra-meningeal involvement was reported, IgG4-HP was defined as systemic IgG4-RD. Non-specified IgG4-HP was retained when data was lacking for classification.

\section{Data availability}

The authors confirm that the data supporting the findings of this study are available within the article and its supplementary materials (e-references e1-e47, links.lww.com/NXI/A115).

\section{Findings}

We report findings from 60 patients that were taken from 42 case reports and 5 case-series. The complete list of bibliographical references is provided in the supplemental data online document.

\section{Patients' characteristics}

Brain involvement was mostly reported (49/60 cases). Spinal cord lesions were described in 16 cases, of which 9 were cervical. Thoracic and lumbar spinal cord lesions were described respectively in 8 and 5 cases. The disease affected both the brain and the spine in 5 patients. Systemic IgG4-RD was noted in 18 cases and mostly accompanied cranial manifestations of IgG4-HP. The extra-meningeal manifestations are reported in figure 2 . Isolated meningeal damage was identified in 25 patients of whom 24 had single-organ IgG4-HP. Seventeen patients could not be classified because of a lack of data.

The demographics, clinical, pathology, and blood work-ups are shown in table 1. Patients with IgG4-HP were mostly males with a male-to-female ratio of 2 . Median age was 53 years (range: 19-82). Headache was common in cases of cerebral IgG4-HP. Visual impairment and cranial nerve palsy were each present in less than one-third of cases.

Plasma IgG4 levels of more than $135 \mathrm{mg} / \mathrm{dL}$ were found in 20 of the 36 patients for whom this information was available. The median level of plasma IgG4 levels was higher in patients with systemic IgG4-RD, whereas meningeal IgG4 infiltration was higher in isolated IgG4-HP. A biological inflammatory syndrome was inconsistently present (10/27 cases) and was more frequently found with systemic involvement. Eosinophilia was only reported in the case of a patient who also presented with eosinophilic granulomatosis with polyangiitis.

\section{CSF analysis}

CSF findings are presented in table 2. Aseptic lymphocyte meningitis was identified in more than half of the specimens with median CSF protein levels of $0.91 \mathrm{~g} / \mathrm{L}$ and a median CSF white blood count of $19.5 / \mathrm{mm} 3$. The CSF profile was generally oligoclonal (5 cases). Intrathecal IgG synthesis was found in 11/13 patients. CSF IgG4 levels were only available for 4 patients, but they were significantly increased with a median value of $5.225 \mathrm{mg} / \mathrm{dL}$ - which is more than 10 times the upper limit of the normal range $(0.32 \mathrm{mg} / \mathrm{dL})$.

\section{Treatment}

Treatment strategies are presented for 53 patients in table 3. Nearly all patients received systemic steroids (48/53), of which 20 received pulse steroid therapy. Relapse occurred in 16 cases and was less frequent in the "pulse therapy" group (13/23 patients vs $3 / 15$ patients). Relapse occurred less frequently when the steroid dose was greater than 49 $\mathrm{mg} / \mathrm{d}$ (relapse rate was $52.6 \%$, whereas it was $100 \%$ with lower dosages). In the same way, the occurrence of relapse was lower when steroid therapy was followed over a longer period of time (100\% relapse for less than 6 months of steroid therapy vs $42.9 \%$ when steroids were continued over a year). All the steroid treatment specific data are available in table e-1, links.lww.com/NXI/A115. 


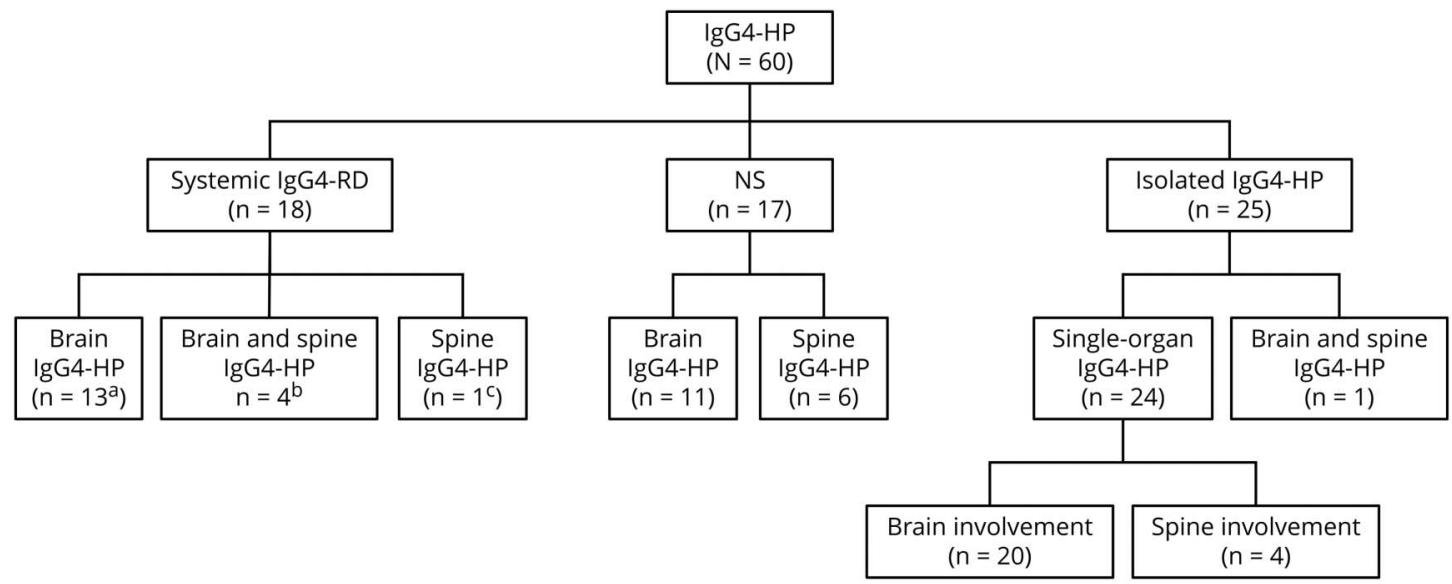

${ }^{a-c}$ Other locations of IgG4-RD involvement by patients: ${ }^{a}$ 1. Orbital pseudotumor, kidney and lung. 2. Pancreas. 3. Lymph nodes, submandibular glands and lung. 4. Retroperitoneal fibrosis. 5. Mastoid. 6. Retroperitoneal fibrosis. 7. Aortitis. 8. Episcleritis. 9. Hypophysitis. 10. Lacrymal and submandibular glands. 11. Orbital pseudotumor. 12. Maxillary pseudotumor. 13. Episcleritis. b1. Orbitory pseudotumor. 2. Pulmonary pseudo-tumor and hypophysitis. 3. Orbitary pseudotumor. 4. Retroperitoneal fibrosis. ${ }^{~} 1$. Submandibular gland. IgG4-HP = IgG 4-related hypertrophic pachymeningitis; IgG4-RD = IgG 4-related disease; NS = non-specified.

Twenty patients were treated surgically, mostly in cases of cerebral involvement. Only 3 patients with systemic IgG4-RD required surgical treatment. Relapse occurred less often when surgery was done ( $33 \%$ vs $44 \%$ without surgery). Surgical treatment was in itself sufficient to achieve disease remission within 6 months (range: 3-12 months) in 4 cases of isolated IgG4-HP.

Table 1 Demographic, clinical, histologic, and blood work-up data

\begin{tabular}{|c|c|c|c|c|c|c|c|c|}
\hline & \multicolumn{2}{|c|}{ Total IgG4-HP } & \multicolumn{2}{|c|}{ Systemic IgG4-HP } & \multicolumn{2}{|c|}{ Isolated IgG4-HP } & \multicolumn{2}{|c|}{ Non-specified IgG4-HP } \\
\hline & $n$ & 60 & $\boldsymbol{n}$ & 18 & $n$ & 25 & $n$ & 17 \\
\hline Median age, $y^{a}$ & 60 & $53(19-82)$ & 18 & $48(32-70)$ & 25 & $52(35-71)$ & 17 & $55(19-82)$ \\
\hline Sex ratio (M/F) & 60 & $2(40 / 20)$ & 18 & $1.6(11 / 7)$ & 25 & $2.1(17 / 8)$ & 17 & $2.4(12 / 5)$ \\
\hline Single brain involvement & 60 & $44(73.3 \%)$ & 18 & $13(72.2 \%)$ & 25 & $20(80 \%)$ & 17 & $11(64.7 \%)$ \\
\hline Single spine involvement & & $11(18.3 \%)$ & & $1(5.6 \%)$ & & $4(16 \%)$ & & $6(35.3 \%)$ \\
\hline Both brain and spine involvement & & $5(8.3 \%)$ & & $4(22.2 \%)$ & & $1(4 \%)$ & & 0 \\
\hline Headaches & 55 & $36(65.4 \%)$ & 17 & $15(88.2 \%)$ & 25 & $15(60 \%)$ & 13 & $6(46.2 \%)$ \\
\hline Visual acuity lost & 55 & $16(29.1 \%)$ & 17 & $6(35.3 \%)$ & 25 & $6(24 \%)$ & 13 & $4(30.8 \%)$ \\
\hline Cranial nerve palsy & 55 & $16(29.1 \%)$ & 17 & $9(52.9 \%)$ & 25 & $6(24 \%)$ & 13 & $1(7.7 \%)$ \\
\hline Epilepsy & 55 & $7(12.7 \%)$ & 17 & $2(11.8 \%)$ & 25 & $5(20 \%)$ & 13 & 0 \\
\hline Motor weakness (limbs) & 55 & $16(29.1 \%)$ & 17 & $3(17.6 \%)$ & 25 & $6(24 \%)$ & 13 & $7(53.8 \%)$ \\
\hline Sensory loss (limbs) & 51 & $9(16.4 \%)$ & 17 & $2(11.8 \%)$ & 24 & $3(12.5 \%)$ & 10 & $4(40 \%)$ \\
\hline Serum IgG4 > $135 \mathrm{mg} / \mathrm{L}$ & 36 & $20(55.6 \%)$ & 12 & $9(75 \%)$ & 19 & $7(36.8 \%)$ & 5 & $4(80 \%)$ \\
\hline Median serum IgG4 (mg/L) ${ }^{a}$ & 29 & 155 (40.1-939) & 11 & $165(54-260)$ & 15 & $97(47-939)$ & 3 & $162(155-182)$ \\
\hline Blood inflammatory syndrome & 27 & $10(37 \%)$ & 7 & $5(71.4 \%)$ & 12 & $3(25 \%)$ & 8 & $2(25 \%)$ \\
\hline Eosinophils $>500 / \mathrm{mm}^{3}$ & 22 & $1(4.5 \%)$ & 4 & $1(25 \%)$ & 11 & 0 & 7 & 0 \\
\hline Median IgG4+/IgG ratio ${ }^{a}$ & 35 & $50.5(40-94)$ & 9 & $49.5(40-70)$ & 15 & $58(40-94)$ & 11 & $50(40-73.3)$ \\
\hline Median IgG4+/HPF ${ }^{a}$ & 39 & $50(10-310)$ & 7 & $51.7(10-310)$ & 18 & $63(10-200)$ & 14 & $40.05(10-140)$ \\
\hline
\end{tabular}

Abbreviations: HPF = high-power field; IgG4 = immunoglobulin G4; IgG4-HP = IgG 4-related hypertrophic pachymeningitis; $n=$ number of patients with available data.

a Range. 
Table 2 Cerebrospinal fluid data

\begin{tabular}{|c|c|c|c|c|c|c|c|c|}
\hline & \multicolumn{2}{|c|}{ Total IgG4-HP } & \multicolumn{2}{|c|}{ Systemic IgG4-HP } & \multicolumn{2}{|c|}{ Isolated IgG4-HP } & \multicolumn{2}{|c|}{ Non-specified IgG4-HP } \\
\hline & $n$ & 60 & $n$ & 18 & $n$ & 25 & $n$ & 17 \\
\hline Protein $>0,4 \mathrm{G} / \mathrm{L}$ & 28 & $21(75 \%)$ & 9 & $7(77.8 \%)$ & 15 & $11(73.3 \%)$ & 4 & $3(75 \%)$ \\
\hline Median protein level $(\mathrm{g} / \mathrm{L})^{\mathrm{a}}$ & 20 & $0.925(0.22-4.17)$ & 7 & $0.83(0.44-1.68)$ & 11 & $0.99(0.22-4.17)$ & 2 & $0.72(0.44-1)$ \\
\hline WBC $>5 / \mathrm{mm}^{3}$ & 30 & $18(60 \%)$ & 11 & $7(63.6 \%)$ & 15 & $7(46.7 \%)$ & 4 & $4(100 \%)$ \\
\hline Median WBC $\left(/ \mathrm{mm}^{3}\right)^{a}$ & 20 & $19.5(0-150)$ & 8 & $23.5(1-112)$ & 9 & $14(0-150)$ & 3 & $17(10-21)$ \\
\hline Median lymphocytes count (\%) ${ }^{a}$ & 18 & $91.5(0-100)$ & 8 & $91.5(85-100)$ & 8 & $94.5(0-100)$ & 2 & $65.5(51-80)$ \\
\hline $\operatorname{lgG}>8 \mathrm{mg} / \mathrm{dL}$ & 13 & $11(84.6 \%)$ & 3 & $3(100 \%)$ & 8 & $6(75 \%)$ & 2 & $2(100 \%)$ \\
\hline Median IgG count (mg/dL) & 10 & $14.3(6.29-38.1)$ & 3 & $14.3(8.7-18.8)$ & 5 & $13.03(6.29-38.1)$ & 2 & $23.8(13.3-34.3)$ \\
\hline Median IgG index ${ }^{a}$ & 6 & $0.965(0.53-1.84)$ & 2 & $1.82(1.8-1.84)$ & 3 & $0.63(0.53-0.84)$ & 1 & 1.09 \\
\hline \multirow[t]{3}{*}{ Profile } & 8 & Oligoclonal (5) & 2 & Oligoclonal (2) & 5 & Oligoclonal (2) & 1 & Oligoclonal (1) \\
\hline & & Transudate (2) & & & & Transudate (2) & & \\
\hline & & Normal (1) & & & & Normal (1) & & \\
\hline Oligoclonal bands & 10 & $7(70 \%)$ & 4 & $3(75 \%)$ & 6 & $4(66.7 \%)$ & 0 & - \\
\hline $\operatorname{lgG} 4>0.32 \mathrm{mg} / \mathrm{dL}$ & 4 & $4(100 \%)$ & 2 & $2(100 \%)$ & 2 & $2(100 \%)$ & 0 & - \\
\hline Median IgG4 (mg/dL) ${ }^{a}$ & 4 & $5.225(4.94-8.5)$ & 2 & $5.05(4.94-5.1)$ & 2 & $6.925(5.35-8.5)$ & 0 & - \\
\hline
\end{tabular}

Abbreviations: IgG4 = immunoglobulin G4; IgG4-HP = IgG 4-related hypertrophic pachymeningitis; $\mathrm{n}$ = number of patients with available data; WBC: white blood cells.

a Range.

Twenty-five patients received an immunosuppressive drug, either as a steroid sparing agent $(11 / 25)$ or after failure to achieve disease control (19/25). RTX was the most used immunosuppressant as first-line (10/25 patients) and secondline therapy ( $6 / 7$ patients). The clinical response was reported for all patients with the first immunosuppressive therapy. The clinical response data for patients who received more than 1 immunosuppressant were available for 7 of the 8 patients. The overall clinical remission was obtained for 24 patients; 11 had isolated IgG4-HP, 11 had systemic IgG4-RD, and 2 had non-specified IgG4-HP. RTX (14 patients) and cyclophosphamide (CYC) (5 patients) were associated with the best response rate in comparison to other drugs. One patient died of an infection with RTX therapy.

\section{Discussion}

IgG4-RD has been described as a multisystemic, fibroinflammatory, and lymphoproliferative disease that is characterized as a polyclonal IgG4-infiltration, leading to storiform fibrosis and oblitering phlebitis. ${ }^{1}$ Histopathologic studies are essential for diagnosis and allow infectious, neoplastic, and/or other inflammatory diseases to be eliminated.

The 2011 Japan College of Rheumatology classification criteria for IgG4-RD are the most commonly used. ${ }^{8}$ Serum IgG4 levels are not specific markers for IgG4-RD, as they also increase in cancerous, allergic, and autoimmune disorders. ${ }^{6,9,10}$ The specificity and positive predictive value of the serum IgG4 for IgG4 $\mathrm{RD}$ are 60 and $34 \%$ respectively. ${ }^{11}$

Meningeal involvement of IgG4-RD is rare and was first described in $2009 .{ }^{12}$ Its prevalence is estimated to be slightly above $2 \%$ of overall clinical manifestations, based on data from recent series. ${ }^{5,6,13-15}$

To the best of our knowledge, we have presented the first case of an arteriovenous dural fistula in IgG4-HP, suggesting it could develop after a local precipitating factor, if ever identified.

Synchronous pachymeningitis of the brain and spinal cord is less common. Clinical manifestations of the disease are subject to localization or complications due to compression and/ or infiltration of neurologic and/or vascular adjacent structures.

IgG4-HP is isolated in more than half of the overall cases contrasting with the preferential multisystemic involvement reported by other authors. ${ }^{13,14,16}$

Serum IgG4 levels were increased in $55.5 \%$ of the studied population. Stone et al. and Zhang et al. identified a prevalence rate ranging from $70 \%$ to $94.1 \%$, respectively. ${ }^{1,5}$ However, using the serum IgG4 level as a diagnostic criteria for 
Table 3 Treatment and relapse characteristics

\begin{tabular}{|c|c|c|c|c|c|c|c|c|}
\hline & \multicolumn{2}{|c|}{ Total IgG4-HP } & \multicolumn{2}{|c|}{ Systemic IgG4-HP } & \multicolumn{2}{|c|}{ Isolated IgG4-HP } & \multicolumn{2}{|c|}{ Non-specified IgG4-HP } \\
\hline & $n$ & 60 & $n$ & 18 & $n$ & 25 & $n$ & 17 \\
\hline Surgical excision & 53 & $20(37.7 \%)$ & 16 & $3(18.8 \%)$ & 25 & $10(40 \%)$ & 12 & $7(58.3 \%)$ \\
\hline Steroid therapy & 53 & $48(90.6 \%)$ & 16 & $16(100 \%)$ & 25 & $21(84 \%)$ & 12 & 11 (91.7\%) \\
\hline Steroid efficacy & 53 & $41(77.4 \%)$ & 15 & 14 (93.3\%) & 22 & $17(77.3 \%)$ & 10 & $9(90 \%)$ \\
\hline IV pulse steroid therapy & 39 & $20(41.7 \%)$ & 12 & $8(66.7 \%)$ & 23 & $10(43.5 \%)$ & 4 & $2(50 \%)$ \\
\hline IV pulse steroid efficacy & 20 & $15(75 \%)$ & 8 & $7(87.5 \%)$ & 10 & $6(60 \%)$ & 4 & $2(50 \%)$ \\
\hline Relapse after steroids & 38 & $16(42.1 \%)$ & 11 & $5(45.4 \%)$ & 19 & $8(42.1 \%)$ & 8 & $3(37.5 \%)$ \\
\hline Relapse after IV pulse steroids & 15 & $3(20 \%)$ & 7 & $2(28.6 \%)$ & 6 & $1(16.7 \%)$ & 2 & 0 \\
\hline IS & 49 & $25(51 \%)$ & 15 & $11(73.3 \%)$ & 22 & $12(54.5 \%)$ & 12 & $2(16.7 \%)$ \\
\hline \multirow[t]{3}{*}{ Efficacy with first line IS } & 25 & $17(68 \%)$ & 11 & (4 RTX, 3 AZA, 2 MTX, 1 CYC, 1 CSA) & & (5 RTX, 4 MTX, 2 CYC, 1 MMF) & & (1 RTX, 1 CYC) \\
\hline & & & & $9(81.8 \%)$ & & $6(50 \%)$ & & \\
\hline & & & & (4 RTX, 2 AZA, 1 MTX, 1 CYC, 1 CSA) & 12 & (3 RTX, 2 CYC, 1 MTX) & 2 & $2(100 \%)$ \\
\hline \multirow[t]{2}{*}{ Efficacy with further line IS } & 8 & $7(87.5 \%)$ & 2 & $2(100 \%)$ & 5 & $5(100 \%)$ & - & - \\
\hline & & & & (2 RTX) & & (3 RTX, 1 itRTX, 1 CYC) & & \\
\hline
\end{tabular}

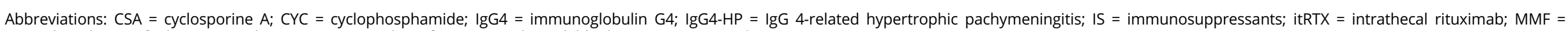
mycophenolate mofetil; MTX = methotrexate; $n=$ number of patients with available data; RTX = rituximab. 
IgG4-RD remains debatable because IgG4 levels are closely related to disease activity and the extent of organ damage. ${ }^{6,10,17}$ It appears that IgG4-HP is infrequently associated with systemic disease and explains normal-to-low serum IgG4 levels and the lack of inflammatory markers. This is further illustrated by a recent study showing that an increase in serum IgG4 is usually associated with lymph node involvement, pancreatic, biliary, and/or ENT features. ${ }^{18}$ On the other hand, skin, prostate, and/or retroperitoneum involvement is associated with lower levels of serum IgG4. ${ }^{18}$ As supported by our review, IgG4-HP is also associated with lower IgG4 plasmatic levels, inflammatory syndrome, eosinophilia, and complement consumption. It is thus essential to ascertain extra-neurologic organ-involvement in patients with IgG4-HP presenting with high serum IgG4 levels and elevated plasma inflammatory markers. In such circumstances, PETCT has been shown to be of diagnostic value. ${ }^{19-21}$

CSF alone is not a reliable parameter for the diagnosis of IgG4-HP. It is, however, common to find lymphocytic meningitis and a moderate increase in CSF proteins with intrathecal synthesis of IgG with oligoclonal bands. Furthermore, Della-Corte et al. ${ }^{22}$ reported that an increase in intrathecal IgG4 levels could be a surrogate marker for neurologic IgG4-RD when tissue biopsies could not be performed.

IgG4-HP closely follows granulomatosis with polyangeitis (GPA) as a leading cause of inflammatory HP. ${ }^{23}$ Other diagnoses to consider are lymphoma, sarcoidosis, tuberculosis, rheumatoid arthritis and Langerhans-cell histiocytosis. ${ }^{24,25}$ Interestingly, increases in plasma IgG4 levels have also been observed in cases of GPA. Therefore, histopathologic studies have to be an integral part of the diagnostic workup. To complicate matters, overlapping syndromes of IgG4-RD and antineutrophil cytoplasmic antibodies-related vasculitides have been described in a French cohort of 18 cases. $^{26}$

There is no specific treatment protocol for meningeal forms of IgG4-RD. Steroids remain the first-line treatment, ${ }^{27}$ though

Figure 3 Treatment algorithm for IgG4-HP

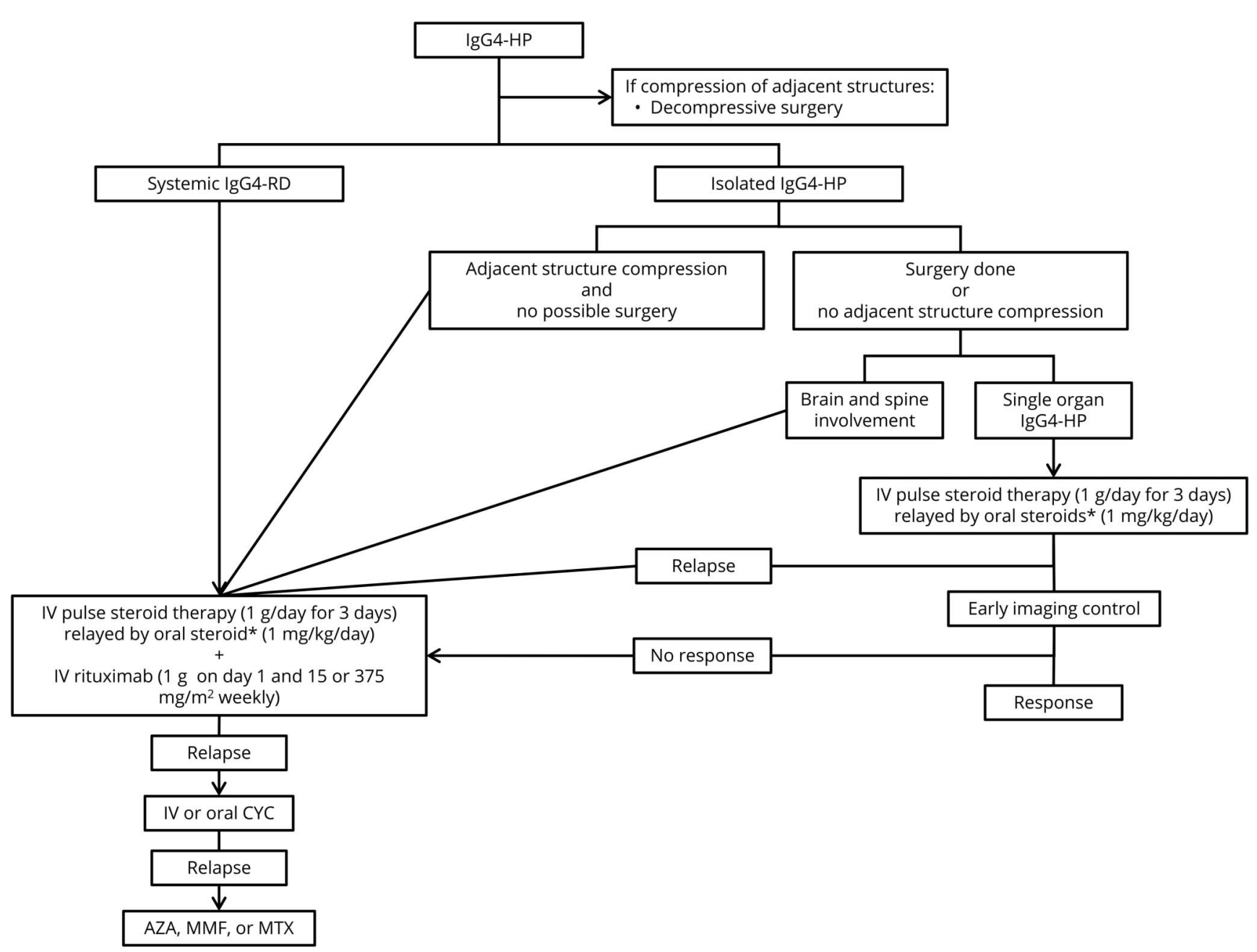

* Oral steroid therapy should be reduced over a period of 1-year minimum. AZA = azathioprine; CYC = cyclophosphamide; IgG4-HP = IgG 4-related hypertrophic pachymeningitis; MMF = mycofenolate mofetil; MTX = methotrexate. 
several other studies also report the efficacy of immunosuppressive agents such as RTX. ${ }^{28,29}$ Short-term response to surgery in single-organ IgG4-HP is good and, in some cases, may be sufficient to achieve remission. Systemic steroids are prescribed for most patients and appear to reduce relapse rate. Patients with early relapse-most often than not-had not received steroid pulse therapy. In addition, relapse is less frequent when oral steroids are prescribed at a minimal dose of $50 \mathrm{mg} / \mathrm{d}$ and are maintained for a minimum of one year period. Because steroids should be continued over a year, immunosuppressive drug use as steroid sparing agent should be considered early on. Though used in half of the patients, immunosuppressive therapy is best suited to multisystem organ-involvement. The clinical response rates are particularly good in patients treated with RTX or CYC. One report even described the efficacy of intrathecal RTX in the event of treatment failure from other immunosuppressors. ${ }^{30}$ Carruthers et al. ${ }^{31}$ published in 2015, a prospective clinical trial of 30 patients, studying the efficacy of RTX in IgG4-RD. Remission, obtained in $77 \%$ of patients, was calculated from a combined score, the Responding Index. The data of our review concord with the literature designating RTX as the immunosuppressive drug of choice for IgG4-RD and IgG4-HP.

The disease-activity score or Responder Index (RI) has been proposed by some authors. ${ }^{31}$ Patients were categorized into high- or low-risk groups for relapse based on serum IgG4 levels, the extent of organ involvement, and organ failure. IgG4-HP is rarely associated with other organ-involvement, but it is known to relapse despite steroid therapy in nearly half of cases, regardless of the type of meningeal involvement. The $\mathrm{RI}$ does not seem to reflect this risk of relapse in cases of isolated IgG4-HP. Because systemic involvement is less frequent in IgG4-HP, serum markers such as $\mathrm{CD} 19^{+}, \mathrm{CD} 27^{+}$, $\mathrm{CD} 20^{-}$, and CD38(hi) cells, IgG4 and IgE levels, ${ }^{32-34}$ may be less reliable than in IgG4-RD with multi-organ involvement for predicting relapse. On the other hand, CSF IgG4 levels may better reflect disease activity in IgG4-HP but would also require regular spinal taps-limiting its use to specific situations (i.e., treatment resistance, initiation of immunosuppressive therapy).

Based on our experience and the available data from previous studies, a treatment algorithm for IgG4-HP is presented in figure 3 .

\section{Conclusion}

IgG4-HP is an uncommon form of IgG4-RD and is one of the leading causes of meningeal inflammatory disease. It is mainly characterized by the lack of extra-neurologic organinvolvement and systemic signs. Histopathologic studies should, when possible, be performed as it is crucial for diagnosis because serum markers are rarely informative. Treatment strategies rely on early surgery, steroids, and early immunosuppressive therapy (such as RTX) to prevent neurologic complications.

\section{Study funding}

No targeted funding.

\section{Disclosure}

M. Levraut reports no disclosures; M. Cohen received honoraria for advisory board participation from Biogen, Novartis, Roche and Ad Scientam; S. Bresch reports no disclosures; C. Giordana received honoraria from Abbvie; F. Burel-Vandenbos reports no disclosures; J. Sedat reports no disclosures; D. Fontaine is a consultant for Medtronic, St Jude-Abott, Autonomic Technologies, Renishaw; V. Bourg reports no disclosures; N. Martis reports no disclosures; C. Lebrun-Frenay received honoraria for expertise and presentations at meetings from Teva, Biogen, Merck, Roche, Novartis. Go to Neurology.org/NN for full disclosures.

\section{Publication history}

Received by Neurology: Neuroimmunology \& Neuroinflammation January 24, 2019. Accepted in final form March 12, 2019.

Appendix Authors

\begin{tabular}{|c|c|c|c|}
\hline Name & Location & Role & Contribution \\
\hline $\begin{array}{l}\text { Michaël } \\
\text { Levraut, MD }\end{array}$ & $\begin{array}{l}\text { Université Côte } \\
\text { d'Azur, Hôpital } \\
\text { l'Archet } 1\end{array}$ & Author & $\begin{array}{l}\text { Major role in acquisition of } \\
\text { data; drafted the } \\
\text { manuscript }\end{array}$ \\
\hline $\begin{array}{l}\text { Mikaël } \\
\text { Cohen, MD }\end{array}$ & $\begin{array}{l}\text { Université Côte } \\
\text { d'Azur, Hôpital } \\
\text { Pasteur } 2\end{array}$ & Author & $\begin{array}{l}\text { Revised the manuscript for } \\
\text { intellectual content }\end{array}$ \\
\hline $\begin{array}{l}\text { Saskia } \\
\text { Bresch, MD }\end{array}$ & $\begin{array}{l}\text { Université Côte } \\
\text { d'Azur, Hôpital } \\
\text { Pasteur } 2\end{array}$ & Author & $\begin{array}{l}\text { Revised the manuscript for } \\
\text { intellectual content }\end{array}$ \\
\hline $\begin{array}{l}\text { Caroline } \\
\text { Giordana, } \\
\text { MD }\end{array}$ & $\begin{array}{l}\text { Université Côte } \\
\text { d'Azur, Hôpital } \\
\text { Pasteur } 2\end{array}$ & Author & $\begin{array}{l}\text { Revised the manuscript for } \\
\text { intellectual content }\end{array}$ \\
\hline $\begin{array}{l}\text { Fanny Burel- } \\
\text { Vandenbos, } \\
\text { MD, PhD }\end{array}$ & $\begin{array}{l}\text { Université Cote } \\
\text { d'Azur, Hôpital } \\
\text { Pasteur } 1\end{array}$ & Author & $\begin{array}{l}\text { Interpreted the data, } \\
\text { revised the manuscript for } \\
\text { intellectual content }\end{array}$ \\
\hline $\begin{array}{l}\text { Lydiane } \\
\text { Mondot, MD }\end{array}$ & $\begin{array}{l}\text { Université Côte } \\
\text { d'Azur, Hôpital } \\
\text { Pasteur } 2\end{array}$ & Author & $\begin{array}{l}\text { Revised the manuscript for } \\
\text { intellectual content }\end{array}$ \\
\hline $\begin{array}{l}\text { Jacques } \\
\text { Sedat, MD }\end{array}$ & $\begin{array}{l}\text { Université Côte } \\
\text { d'Azur, Hôpital } \\
\text { Pasteur } 2\end{array}$ & Author & $\begin{array}{l}\text { Revised the manuscript for } \\
\text { intellectual content }\end{array}$ \\
\hline $\begin{array}{l}\text { Denys } \\
\text { Fontaine, } \\
\text { MD, PhD }\end{array}$ & $\begin{array}{l}\text { Université Côte } \\
\text { d'Azur, Hôpital } \\
\text { Pasteur } 2\end{array}$ & Author & $\begin{array}{l}\text { Revised the manuscript for } \\
\text { intellectual content }\end{array}$ \\
\hline $\begin{array}{l}\text { Véronique } \\
\text { Bourg, MD }\end{array}$ & $\begin{array}{l}\text { Université Côte } \\
\text { d'Azur, Hôpital } \\
\text { Pasteur } 2\end{array}$ & Author & $\begin{array}{l}\text { Revised the manuscript for } \\
\text { intellectual content }\end{array}$ \\
\hline $\begin{array}{l}\text { Nihal Martis, } \\
\text { MD }\end{array}$ & $\begin{array}{l}\text { Université Côte } \\
\text { d'Azur, Hôpital } \\
\text { l'Archet } 1\end{array}$ & Author & $\begin{array}{l}\text { Designed and } \\
\text { conceptualized the study; } \\
\text { revised the manuscript for } \\
\text { intellectual content }\end{array}$ \\
\hline
\end{tabular}

Continued 
Appendix (continued)

\begin{tabular}{|c|c|c|c|}
\hline Name & Location & Role & Contribution \\
\hline $\begin{array}{l}\text { Christine } \\
\text { Lebrun- } \\
\text { Frenay, MD, } \\
\text { PhD }\end{array}$ & $\begin{array}{l}\text { Université Côte } \\
\text { d'Azur, Hôpital } \\
\text { Pasteur } 2\end{array}$ & Author & $\begin{array}{l}\text { Designed and } \\
\text { conceptualized the study } \\
\text { revised the manuscript }\end{array}$ \\
\hline
\end{tabular}

\section{References}

1. Stone JH, Zen Y, Deshpande V. IgG4-related disease. N Engl J Med 2012;366: 539-551.

2. Deshpande V, Zen Y, Chan JK, et al. Consensus statement on the pathology of IgG4 related disease. Mod Pathol 2012;25:1181-1192.

3. Kim EC, Lee SJ, Hwang HS, Kim J, Kim MS. Bilateral diffuse scleritis as a first manifestation of immunoglobulin G4-related sclerosing pachymeningitis. Can J Ophthalmol 2013;48:e31-e33.

4. Wallace ZS, Carruthers MN, Khosroshahi A, et al. IgG4-related disease and hypertrophic pachymeningitis. Medicine (Baltimore) 2013;92:206-216.

5. Zhang PP, Zhao JZ, Wang M, et al. The clinical characteristics of 346 patients with IgG4-related disease [in Chinese]. Zhonghua Nei Ke Za Zhi 2017;56: 644-649.

6. Wallace ZS, Deshpande V, Mattoo H, et al. IgG4-Related disease: clinical and laboratory features in one hundred twenty-five patients. Arthritis Rheumatol 2015;67: 2466-2475.

7. Lindstrom KM, Cousar JB, Lopes MBS. IgG4-related meningeal disease: clinicopathological features and proposal for diagnostic criteria. Acta Neuropathol 2010;120: $765-776$.

8. Umehara H, Okazaki K, Masaki Y, et al. Comprehensive diagnostic criteria for IgG4related disease (IgG4-RD), 2011. Mod Rheumatol 2012;22:21-30.

9. Su Y, Sun W, Wang C, et al. Detection of serum IgG4 levels in patients with IgG4related disease and other disorders. PLoS One 2015;10:e0124233.

10. Culver EL, Sadler R, Simpson D, et al. Elevated serum IgG4 levels in diagnosis, treatment response, organ involvement, and relapse in a prospective IgG4-related disease UK cohort. Am J Gastroenterol 2016;111:733-743.

11. Carruthers MN, Khosroshahi A, Augustin T, Deshpande V, Stone JH. The diagnostic utility of serum IgG4 concentrations in IgG4-related disease. Ann Rheum Dis 2015; 74:14-18.

12. Chan S-K, Cheuk W, Chan K-T, Chan JKC. IgG4-related sclerosing pachymeningitis. Am J Surg Pathol 2009;33:1249-1252.

13. Sekiguchi H, Horie R, Kanai M, Suzuki R, Yi ES, Ryu JH. IgG4-Related disease: retrospective analysis of one hundred sixty-six patients. Arthritis Rheumatol 2016;68: 2290-2299.

14. Inoue D, Yoshida K, Yoneda N, et al. IgG4-related disease: dataset of 235 consecutive patients. Medicine (Baltimore) 2015;94:e680.
15. Lin W, Lu S, Chen $\mathrm{H}$, et al. Clinical characteristics of immunoglobulin G4-related disease: a prospective study of 118 Chinese patients. Rheumatology (Oxford) 2015;54:1982-1990.

16. Chen Y, Zhao JZ, Feng RE, et al. Types of organ involvement in patients with immunoglobulin G4-related disease. Chin Med J 2016;129:1525-1532.

17. Tabata T, Kamisawa T, Takuma K, et al. Serial changes of elevated serum IgG4 levels in IgG4-related systemic disease. Intern Med 2011;50:69-75.

18. Umehara H, Okazaki $\mathrm{K}$, Nakamura $\mathrm{T}$, et al. Current approach to the diagnosis of IgG4-related disease-combination of comprehensive diagnostic and organ-specific criteria. Mod Rheumatol 2017;27:381-391.

19. Takahashi H, Yamashita H, Morooka M, et al. The utility of FDG-PET/CT and other imaging techniques in the evaluation of IgG4-related disease. Joint Bone Spine 2014 81:331-336.

20. Lee J, Hyun SH, Kim S, et al. Utility of FDG PET/CT for differential diagnosis of patients clinically suspected of IgG4-related disease. Clin Nucl Med 2016;41:e237-e243.

21. Zhang J, Chen H, Ma Y, et al. Characterizing IgG4-related disease with 18F-FDG PET/CT: a prospective cohort study. Eur J Nucl Med Mol Imaging 2014;41: 1624-1634.

22. Della-Torre E, Galli L, Franciotta D, et al. Diagnostic value of IgG4 indices in IgG4related hypertrophic pachymeningitis. J Neuroimmunol 2014;266:82-86.

23. Yonekawa $\mathrm{T}$, Murai $\mathrm{H}$, Utsuki $\mathrm{S}$, et al. A nationwide survey of hypertrophic pachymeningitis in Japan. J Neurol Neurosurg Psychiatry 2014;85:732-739.

24. AbdelRazek MA, Venna N, Stone JH. IgG4-related disease of the central and peripheral nervous systems. Lancet Neurol 2018;17:183-192.

25. Kamisawa T, Zen Y, Pillai S, Stone JH. IgG4-related disease. Lancet 2015;385 $1460-1471$.

26. Danlos F-X, Rossi GM, Blockmans D, et al. Antineutrophil cytoplasmic antibodyassociated vasculitides and IgG4-related disease: a new overlap syndrome. Autoimmun Rev 2017;16:1036-1043.

27. Khosroshahi A, Wallace ZS, Crowe JL, et al. International consensus guidance statement on the management and treatment of IgG4-related disease. Arthritis Rheumatol 2015;67:1688-1699.

28. Ebbo M, Grados A, Samson M, et al. Long-term efficacy and safety of rituximab in IgG4-related disease: data from a French nationwide study of thirty-three patients. PLoS One 2017;12:e0183844.

29. Carruthers MN, Topazian MD, Khosroshahi A, et al. Rituximab for IgG4-related disease: a prospective, open-label trial. Ann Rheum Dis 2015;74:1171-1177.

30. Della-Torre E, Campochiaro C, Cassione EB, et al. Intrathecal rituximab for IgG4 related hypertrophic pachymeningitis. J Neurol Neurosurg Psychiatry 2018;89: 441-444.

31. Carruthers MN, Stone JH, Deshpande V, Khosroshahi A. Development of an IgG4 $\mathrm{RD}$ responder index. Int J Rheumatol 2012;2012:259408.

32. Wallace ZS, Mattoo H, Carruthers M, et al. Plasmablasts as a biomarker for IgG4 related disease, independent of serum IgG4 concentrations. Ann Rheum Dis 2015;74 190-195.

33. Mattoo H, Mahajan VS, Della-Torre E, et al. De novo oligoclonal expansions of circulating plasmablasts in active and relapsing IgG4-related disease. J Allergy Clin Immunol 2014;134:679-687.

34. Wallace ZS, Mattoo H, Mahajan VS, et al. Predictors of disease relapse in IgG4-related disease following rituximab. Rheumatology (Oxford) 2016;55:1000-1008. 


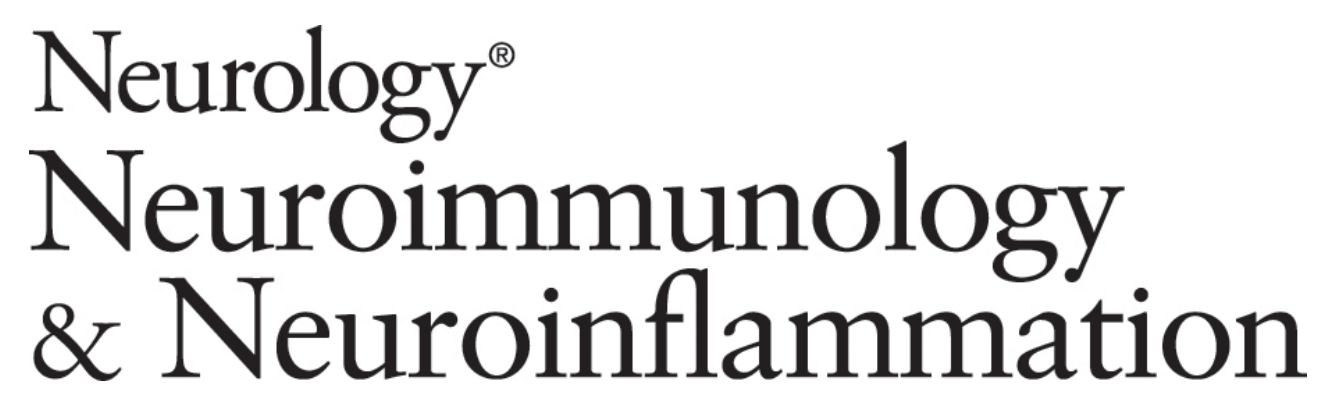

Immunoglobulin G4-related hypertrophic pachymeningitis: A case-oriented review

Michaël Levraut, Mikaël Cohen, Saskia Bresch, et al.

Neurol Neuroimmunol Neuroinflamm 2019;6;

DOI 10.1212/NXI.0000000000000568

This information is current as of May 7, 2019

Neurol Neuroimmunol Neuroinflamm is an official journal of the American Academy of Neurology.

Published since April 2014, it is an open-access, online-only, continuous publication journal. Copyright

Copyright $\odot 2019$ The Author(s). Published by Wolters Kluwer Health, Inc. on behalf of the American

Academy of Neurology.. All rights reserved. Online ISSN: 2332-7812.

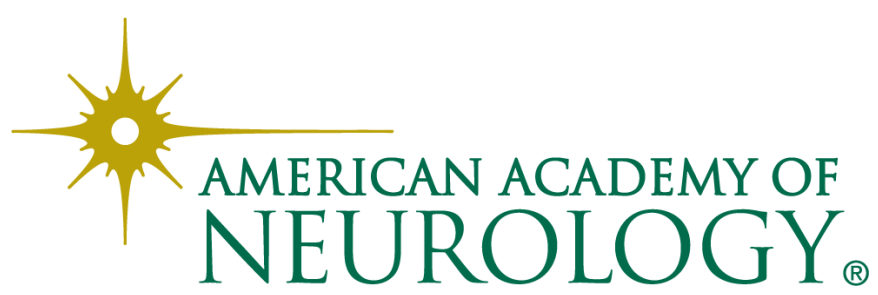




\section{Updated Information \& Services}

References

Citations

Subspecialty Collections

Permissions \& Licensing

Reprints including high resolution figures, can be found at: http://nn.neurology.org/content/6/4/e568.full.html

This article cites 34 articles, 5 of which you can access for free at: http://nn.neurology.org/content/6/4/e568.full.html\#\#ref-list-1

This article has been cited by 2 HighWire-hosted articles: http://nn.neurology.org/content/6/4/e568.full.html\#\#otherarticles

This article, along with others on similar topics, appears in the following collection(s):

All Immunology

http://nn.neurology.org//cgi/collection/all_immunology

All Medical/Systemic disease

http://nn.neurology.org//cgi/collection/all_medical_systemic_disease

All Spinal Cord

http://nn.neurology.org//cgi/collection/all_spinal_cord

Autoimmune diseases

http://nn.neurology.org//cgi/collection/autoimmune_diseases

MRI

http://nn.neurology.org//cgi/collection/mri

Information about reproducing this article in parts (figures,tables) or in its entirety can be found online at:

http://nn.neurology.org/misc/about.xhtml\#permissions

Information about ordering reprints can be found online:

http://nn.neurology.org/misc/addir.xhtml\#reprintsus

Neurol Neuroimmunol Neuroinflamm is an official journal of the American Academy of Neurology.

Published since April 2014, it is an open-access, online-only, continuous publication journal. Copyright

Copyright $\odot 2019$ The Author(s). Published by Wolters Kluwer Health, Inc. on behalf of the American

Academy of Neurology.. All rights reserved. Online ISSN: 2332-7812.

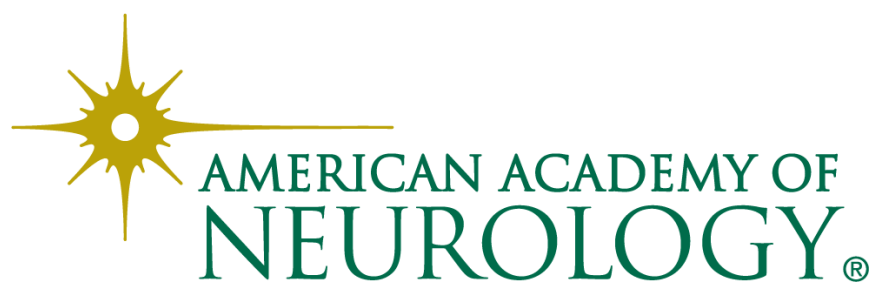

